\title{
ВИКОРИСТАННЯ ЗАСАД ДОКАЗОВОЇ МЕДИЦИНИ ПРИ ВИВЧЕННІ ПИТАНЬ ЗАСТОСУВАННЯ ОРАЛЬНИХ КОНТРАЦЕПТИВІВ
}

\author{
С. Л. Маланчук, В. В. Шманько, Л. М. Маланчук, О. А. Франчук
}

ДВНЗ “Тернопільський державний медичний університет імені І. Я. Горбачевського МОЗ Украӥни”

\section{USING OF PRINCIPLES OF EVIDENCE-BASED MEDICINE IN STUDYING THE ISSUES OF PERORAL APPLICATION OF CONTRACEPTION}

\author{
S. L. Malanchuk,V. V. Shmanko, L. M. Malanchuk, O. A. Franchuk \\ SHEI "Ternopil State Medical University by I. Ya. Horbachevsky of MPH of Ukraine"
}

\begin{abstract}
Доказова медицина - корисний інструмент для практичного лікаря та інших працівників системи охорони здоров'я. Ї̈і впровадження в навчальний процес закономірно обгрунтовано вимогами сьогодення.
\end{abstract}

Evidence-based medicine is a useful tool for a practical physician and other health care workers. Its implementation in educational process is naturally proved by demands of today.

Вступ. Провідні європейські медичні університети ввели в обов'язковий курс навчальної програми клінічну епідеміологію як одну з фундаментальних дисциплін. Основним для доказової медицини (ДМ) $€$ використання принципу доказовості на будь-якому рівні прийняття рішень - від державної програми до індивідуального призначення лікаря. Цей спосіб відноситься не лише до лікувальних втручань, а й до питань діагностики і профілактики. Цей інструмент (ДМ) слід використовувати і у фармацевтичній сфері.

Основна частина. Доказова медицина (англ. Evidence-based medicine - медицина, заснована на доказах, ДМ) - це розділ медицини, заснований на доказах, що припускає пошук, порівняння, узагальнення й широке розповсюдження отриманих доказів для використання в інтересах пацієнтів (Evidence Based Medicine Working Group, 1993).

В більшості розвинутих країн Європи введені загальноприйняті правила проведення клінічних досліджень, такі як стандарт GSP ( Good Clinical Practice, "Незалежна клінічна практика"), а також правила виробництва лікарських засобів (стандарт GMP) i виконання лабораторних досліджень ( стандарт GLP).

Традиційне клінічне навчання оріснтоване на патогенез розвитку захворювання на основі біохімічних, анатомічних, фізіологічних та інших фундаментальних наук. Проте такі клінічні прогнози є тільки гіпотезами і повинні пройти перевірку клінічними дослідженнями. Механізм розвитку захворювання можна зрозуміти лише частково, адже на кінцевий результат впливає багато інших факторів (генетичних, екологічних, соціальних). В історії є багато прикладів медичних втручань, які теоретично повинні були забезпечити лікувальний ефект. Згадаймо добре теоретично обгрунтоване використання діетилстільбестролу в лікуванні загрози переривання вагітності в $60-\mathrm{x}$ роках. Через десятиліття медики стикнулися 3 катастрофічними наслідками - аденокарцинома піхви в популяції дівчаток, мами котрих під час вагітності отримували препарат. Тому практика доказової медицини необхідна у повсякденній роботі не лише практичного лікаря, але й інших працівників системи охорони здоров'я, в тому числі й фармацевтична складова.

Репродуктивне здоров'я, як складова загального здоров'я, є якісним показником ставлення до жінок та дітей будь-якого суспільства.

3 огляду на несприятливу демографічну ситуацію в Україні, постійне зниження загального рівня здоров'я населення, Постановою Кабінету Міністрів України було прийнято низку національних програм з питань репродуктивного здоров'я тапланування сім'ї, зокрема “Репродуктивне здоров'я нації', розраховану до 2015 року. Ця програма має на меті подолання несприятливих демографічних тенденцій, формування в суспільстві потреби повноцінної родини, народження бажаних дітей.

Однією з складових системи планування сім'ї $\epsilon$ контрацепція - альтернатива попередження небажаної вагітності.

(ㄷ. С. Л. Маланчук, В. В. Шманько, Л. М. Маланчук, О. А. Франчук 
Результати численних досліджень підтверджують економічну вигідність як для сім’і, так і для системи охорони здоров'я держави проведення активної роботи щодо планування сім'ї шляхом ефективного застосування методів контрацепції.

Попередження непланової вагітності є стратегічним резервом зменшення як малюкової, так і материнської смертності.

Ефективне використання різних методів контрацепції дозволить вирішити питання штучного переривання вагітності, як одного з грізних чинників материнської захворюваності та смертності. Опитування жінок щодо ставлення їх до абортів свідчить про низький рівень знань у цій сфері. Половина респондентів вказує на негативний вплив аборту на стан здоров’я, а близько 20 \% дотримуються протилежної думки. 3 іншого боку, близько 36 \% опитаних використовують неефективні методи контрацепції, 8 \% взагалі не користуються цими засобами, і лише 56 \% користуються тим чи іншим методом контрацепції.

Виявлено три основні причини невикористання жінками сучасних методів контрацепції: небажання жінки та партнера - 46,8 \%; недоступність методу 11,4 \%; відсутність інформації-21,0%.

Така несприятлива ситуація спонукає до активного впровадження ефективних заходів з питань попередження небажаної вагітності, а саме забезпечення медичних спеціалістів сучасними науковими даними 3 питань планування сім’і; населення сучасними доступними матеріалами та засобами попередження непланової вагітності.

Наукові дослідження з моніторингу заходів планування сім'ї дозволили виявити взаємозв' язок між репродуктивною поведінкою жінки і станом їі здоров'я. Доведено, що самостійно прийняте рішення жінкою щодо вибору методу контрацепції значно підвищуєії комплаєнтність. Підбір засобу контрацепції спеціалістами фармації, медичними працівниками та споживачами повинен грунтуватися на його ефективності, зручності у використанні, мінімальномуризику ускладнень, економічній доступності. Слід враховувати, щопротизаплідний ефект в більшості випадків повинен бути зворотним. Використання будь-якого засобу контрацепції не повинно порушувати фізіологію статевого акту, викликати негативні емоції, знижувати якість життя.

Впровадження в практику постійної ефективної післяабортної та післяпологової контрацепції дозволить попередити аборти у 250 тис. жінок щороку.

Впровадження нормативного забезпечення діяльності центрів планування сім’ї щодо питань контрацепції, з одного боку, дозволить підвищити рівень ква- ліфікації суб' єктів, що надають послуги, а з іншого підвищити рівень культури населення з питань планування родини та безпечного материнства.

Впровадження застосування контрацептивів для населення здійснюється відповідно до діючого законодавства України. Закон України про лікарські засоби, Закон України про рекламу, Постанова КМУ "Про затвердження правил торгівлі лікарськими засобами в аптечних закладах”, наказ МО3 України № 229 від 26.09.2000 р. “Про затвердження порядку державної реєстрації медичної техніки та виробів медичного призначення”, наказ МО3 України № 121 від 06.07.1994 p. "Про застосування методів стерилізації громадян”.

В Україні лише 6 \% жінок, які використовують методи контрацепції, надають перевагу оральним контрацептивам. Для порівняння, в Свропі цю групу складають 46,9\%.

Контрацептиви відносяться до найбільш досліджених препаратів у світі. Ці дослідження проводились для вивчення якості і безпечності протизаплідних засобів, щоб спеціалісти фармації і медицини та користувачі могли переконатися в перевагах застосування контрацептивів над небажаною вагітністю.

Розвіявся міф ризику смерті в результаті прийому контрацептивних засобів. Широкомасштабні дослідження довели, що вміст естрогену менше 35 мкг $€$ безпечним і знижує можливість виникнення побічних ефектів. Було виявлено, що низько дозовані пероральні контрацептиви (20 мкг етинілестрадіолу) призводять до змін характеру менструальної кровотечі, решта досліджень продемонстрували відсутність взаємозв' язку між їх застосуванням і збільшенням маси тіла (Gallo M. F., Lopez L. M. et al., 2009).

Дослідження Marchbanks P. et al., 2002, Dumeaux J. et al., 2003\&2005; Kahlenberg C. et al., 2006; Kumle M. et al., 2002; Vessey M. et al., 2006 продемонстрували відсутність взаємозв' язку застосування оральних контрацептивів та розвитку раку молочної залози.

Використання комбінованих оральних контрацептивів не приводить до безпліддя. В процесі досліджень пероральних контрацептивів було виявлено цілу низку переваг для здоров'я жінки, окрім контрацептивного ефекту, а саме: профілактика остеопенії, дисфункціональних маткових кровотеч, порушення менструального циклу, кіст яєчників, лікування акне Hatcher R. et al., 2004; Kaunitz A. O., 1999).

Оральні контрацептиви мають виражений проективний ефект проти раку ендометрія, яєчників (Hatcher R. etal., 2004; Schesselman J. J., 1995; Mclaughlin J. R. et. al., 2007); сприяють запобіганню позаматковій вагітності 
(A meta-analisis/Contraception 1995; 52:337-341).

Відносний ризик раку шийки матки є підвищеним серед користувачів оральних контрацептивів і зменшується після припинення використання, ризик раку шийки матки є подібним до ризику серед тих, хто ніколи не використовував оральні контрацептиви (Hannaford P. C., Selveraj S., Elliot A. M., Angus V., Iversen L., Lee A. J.).

Два великих дослідження типу випадок-контроль вивчали вплив низько дозованих комбінованих оральних контрацептивів на розвиток доброякісних пухлини печінки. Результати не підтвердили підвищеного ризику розвитку останніх.

\section{Література}

1. Медицинские критерии приемлемости для использования методов контрацепции / Всемирная организация здравоохранения. - [3-е изд.]. -2004.

2. Основы репродуктивной медицины : практическое руководство / под ред. проф. В. К. Чайки. - Донецк : ООО “Альматео", 2001.-С. 620.

3. Свод практических рекомендаций по применению средств контрацепции / Всемирная организация здравоохранения. - [2-е изд.]. -2005.

4. Основи консультування з питань репродуктивного та
Висновки. Вищенаведені приклади свідчать про необхідність введення в навчальну програму студентів фармацевтичного факультету, медичного практичної доказової медицини, що дозволить підвищити не лише їх фаховий рівень. Інформаційне забезпечення щодо вибору методу контрацепції $є$ необхідним кроком для збереження репродуктивного здоров'я нації та ії відтворення. Одним із державних заходів підвищення рівня інформованості населення 3 питань планування сім'ї та раціонального застосування засобів контрацепції є підвищення кваліфікації лікарів та фармацевтичних працівників.

сексуального здоров’я : навчально-методичний посібник / під заг. ред. Б. М. Ворника. - К.: ВЦ “День печати”, 2004. $248 \mathrm{c}$.

5. Планування сім'ї. Навчальний посібник / За ред. Н. Я. Жилка, І. Б. Вовк. -Київ, 2006. -236 с.

6. Фармацевтична опіка при використанні засобів контрацепції. Навчальний посібник. - Київ : Книга плюс, 2010. $-175 \mathrm{c}$.

7. Managing Contraception 2003-2004, Robert A. Hatcher, MD, MPH. 